\title{
Technical Efficiency of Ginger Production in Ilam District of Nepal: A Stochastic Production Frontier Approach
}

\author{
Dikshya Khatiwada ${ }^{1}{ }^{1}$ and Pappu Yadav iD $^{2}$ \\ ${ }^{1}$ Agriculture and Forestry University, Rampur, Chitwan, Nepal \\ ${ }^{2}$ Maharaja Ranjit Singh Punjab Technical University, Punjab, India \\ Correspondence should be addressed to Dikshya Khatiwada; dikshyakhatiwada1107@gmail.com
}

Received 26 September 2021; Accepted 11 January 2022; Published 8 February 2022

Academic Editor: Durgesh Jaiswal

Copyright (c) 2022 Dikshya Khatiwada and Pappu Yadav. This is an open access article distributed under the Creative Commons Attribution License, which permits unrestricted use, distribution, and reproduction in any medium, provided the original work is properly cited.

\begin{abstract}
This study measured the level of technical efficiency among smallholder ginger growers and examined the determinants of inefficiency by employing the stochastic frontier production function. The paper used a simple random sampling technique to interview 100 ginger farmers in Ilam, a leading ginger-producing district in Nepal, with the help of a pretested interview schedule. The STATA.13 software was used to obtain both stochastic frontier estimates and the determinants of technical inefficiency. The results revealed that the average farm-level technical efficiency is $67.8 \%$ which shows the scope of increasing the technical efficiency by $32.2 \%$. The coefficients of seed and farmyard manure were positive and showed significant relation to ginger output at a $1 \%$ and $5 \%$ level of significance, respectively. Education level, training, and membership in cooperatives had a negative and significant impact on technical inefficiency, whereas areas under ginger production had a positive impact on technical inefficiency. Hence, improving the technical knowledge of farmers through training on optimum input use complemented with motivation to join agriculture cooperatives and farmer's associations may increase the technical efficiency of ginger growers in the study area.
\end{abstract}

\section{Introduction}

Agriculture is central to the livelihood of Nepalese people which contributes $27.6 \%$ to the national GDP (Gross Domestic Product) [1]. Around 400,000 Nepalese farmers are engaged in ginger farming [2]. Globally, Nepal is the fourth largest producer of ginger which translates to $9.2 \%$ of the world's production in 2019, while India and China have $35.2 \%$ and $18.3 \%$ of the global share, respectively. The total area under cultivation of ginger in Nepal was 23,500 hectares (ha) with the production of 298,945 metric ton (MT) in the fiscal year 2019/20 [3]. However, the mean yield of ginger in Nepal is only 12.3 tons per hectare [4], which is almost $50 \%$ lower than the potential yield of 24.5 tons per hectare [5]. Ginger is identified as one of the 12 priority export products by the Nepal Trade Integration Strategy-2017 considering its strength induced by favourable geoclimatic condition and its high quality and acknowledging increasing demand in the global market. Until 2020, the Nepal Trade Integration
Strategy aims to increase the export price for Nepalese ginger via value addition in the country from 217 US\$/MT to 815 US\$/MT. According to FAO statistics 2017, Nepal exports more than $60 \%$ of its production and more than $98 \%$ of the total export volume goes to the Indian market. About $75 \%$ of Nepalese ginger is traded in fresh form, and the remaining $25 \%$ in processed form, mainly as Sutho (ginger dried in a traditional way) and powdered ginger [2]. Nepal has comparative advantages in producing the ginger crop, which is evident with comparatively lower labour wages, welladapted local varieties, and established marketing networks [6].

Ilam, Salyan, Palpa, Kaski, Parasi, Panchthar, Morang, Doti, Kailali, and Sindhuli are the top ten producers of ginger in Nepal together occupied about $57.6 \%$ of the country's total production [4]. Ilam is the largest district in terms of ginger production, where ginger is commercially grown in 15 out of the 48 VDCs [7]. The total area under ginger production in the Ilam district in 2019/2020 was 
3,233 ha with a total production of $47,500 \mathrm{MT}$ and yield of 14.69 MT/ha. Ilam district shares $15.88 \%$ of total national ginger production and shares $13.75 \%$ of the total cultivated land area [3]. Ginger has a great impact on smallholder farmers because of its high value and has huge potential to alleviate rural poverty [8].

In the present context, ginger farmers in Nepal face a major problem of frequent price fluctuation, decreasing price trend, high cost of production, and low level of production [9]. Ginger farming in Nepal is labour-intensive; practically, all the operations including planting, mulching, fertilizing, weed control, harvesting, and processing are done manually. These labour costs share $35 \%$ of total cost of production [8]. This has severe implications, that is, it reduces the hectarage that each individual farmer can cultivate and increases the number of labour input. Small-scale conventional farming, lack of improved cultivars, insufficient technical knowledge, limited extension services, and the incidence of rhizome rot and bacterial wilt are the key problems of ginger production in Nepal $[5,8,10]$. Rhizome rot and bacterial wilt are the common and devastating diseases of ginger that can cause more than $50 \%$ yield losses [10]. All these existing problems have constrained ginger yield below 15 tons per hectare and demotivated the farmers to invest in ginger cultivation [11]. The less than optimal performance of ginger implies that there exists a need to study the efficiency of production since ginger production and trade could be a potential enterprise contributing significantly to the national economy of Nepal [6]. One way to increase the production of ginger is by improving the technical efficiency of resource use. Measuring efficiency is important because it can guide resource utilization and may lead to considerable resource savings, which have important implications for both policy formulation and farm management [12]. It is important to think about the reallocation of existing resources to have more output with a given level of input combinations.

Technical efficiency refers to the ability of a firm to employ the best practices in their production process so that the best level of output is produced by using not more than the necessary amount of a given set of input [13]. It is the measure of a firm's success in producing maximum output from a given set of inputs [14]. The frontier measure of efficiency implies that efficient firms are those operating on the production frontier. The amount by which a firm lies below its production frontier is regarded as the measure of inefficiency [15]. There are four major approaches to the measurement of efficiency [16]: the nonparametric programming approach [17], the parametric programming approach [18, 19], the deterministic statistical approach [20-22], and the stochastic frontier approach [23, 24].

Works of literature on the economic aspect of ginger production in Nepal are limited. The available studies only include descriptive and value chain analysis. This study will be the first to profile the technical efficiency of smallholder ginger farmers in Nepal and examine its potential for further improvement. We used the stochastic production frontier method to estimate the technical efficiency of smallholder ginger farmers in the study area. This study helps to enhance the knowledge regarding the efficiency of ginger production by revealing the level of resource use efficiency and determinants of the inefficiency of ginger growing households of Ilam, Nepal.

\section{Materials and Methods}

2.1. Study Site. Ilam district is the largest producer of ginger in Nepal and is selected as the study area. It lies within the coordinates of $26^{\circ} 54^{\prime} 33.95^{\prime \prime} \mathrm{N}$ to $87^{\circ} 55^{\prime} 41.66^{\prime \prime} \mathrm{E}$ with an area of 1703 square kilometers. The climate in Ilam is warm and temperate favourable for producing cash crops such as ginger, potato, red round chilli, tea, broom grass, and cardamom. The district has an average temperature of $18.7^{\circ} \mathrm{C}$ and annual rainfall of $3194 \mathrm{~mm}$ [25]. We purposively selected Ilam Municipality Ward (Ward is the lowest administrative body in Nepal.) no. 9 and 12 because these areas were declared as ginger pocket (Pocket is the primary agricultural production centre at district level with a minimum area of 10 hectares of cultivated areas of particular commodity.) and block (Block is the commercial agricultural production centre with minimum infrastructure and a minimum area of 100 hectares of cultivated areas of particular commodity.), respectively, under Prime Minister Agriculture Modernization Project (PMAMP) (The PMAMP is a 10-year project of the Ministry of Agriculture and Livestock Development, Nepal, introduced in fiscal 2016-17 aiming to transform the country's agricultural sector from subsistence farming to commercial farming.).

2.2. Sampling and Data Collection. Following [26, 27], a semistructured questionnaire was designed for the study comprising questions on socioeconomic characteristics, area under ginger production, human labour input, bullock hours, ginger output, seed quantity, and fertilizer type and quantity. Then, we pretested it by administering it to 10 randomly selected ginger growers of the Ilam district and prepared the final questionnaire by taking due consideration of the suggestion obtained during pretesting. We collected a list of registered ginger farmers from the Ilam Municipal Office and selected 100 ginger growers of Ilam Municipality comprising 50 farmers from ward no. 9 and the remaining 50 from ward no. 12 by using a simple random sampling technique. The data collection was carried out from August to September 2021 by visiting each farm personally and interviewing them with the help of a pretested interview schedule.

2.3. Stochastic Production Frontier Model. Among the various approaches developed to estimate productive efficiency, the stochastic frontier production function approach [23] and the data envelopment analysis [17] are the most popular. In agricultural production where data are likely to be greatly influenced by systematic errors due to the effects of weather conditions, climate change, diseases, etc., the stochastic frontier approach is considered more appropriate than the DEA approach [28]. DEA is a nonparametric or mathematical programming approach for considering optimum 
solutions relative to individual firms rather than assuming, as in optimized regression, that a solution applies to each decision-making unit [17]. A recognized limitation of using DEA to assess technical efficiency is that recommendations for decreasing input usage or expanding output levels are in terms of scalar valued ratios which are held constant. The stochastic frontier approach is preferred when assessing agricultural efficiency because of the inherent stochasticity involved [29, 30]. One advantage of this model is that it contains an inefficiency component which is used statistically to test for the degree of technical inefficiency of households [15, 31-34] and is also less sensitive to outliers [35].

The stochastic frontier production function was independently proposed by Aigner et al. [23] and Meeusen and Broeck [36]. According to Battese [37], the stochastic frontier production function can be expressed in the following equation:

$$
Y_{i}=f\left(X_{i} ; \beta\right) \exp \left(V_{i}-U_{i}\right)
$$

where $Y_{i}=$ output of the $i$ th farm, $\beta=$ vector parameters to be estimated, $V_{i}-U_{i}=$ composite error term, $V_{i}$ denotes the random error not under the control of the farmers, assumed to be independently and identically distributed as $N\left(0, \delta_{v}^{2}\right)$ independently of $U_{i}$ which is the nonnegative random variable associated with technical inefficiency and is identically and independently distributed as truncated normal, with truncations at zero of the normal distribution [38].

The technical efficiency of an individual farm is defined in terms of ratio of the observed output $\left(Y_{i}\right)$ to the corresponding frontier output $\left(Y_{i}^{*}\right)$, conditioned on the level of input used by the farm. It is mathematically expressed as follows:

$$
\begin{aligned}
& \mathrm{TE}=\frac{Y_{i}}{Y_{i}^{*}}, \\
& \mathrm{TE}=\frac{f\left(X_{i} ; \beta\right) \exp \left(V_{i}-U_{i}\right)}{f\left(X_{i} ; \beta\right) \exp \left(V_{i}\right)}, \\
& \mathrm{TE}=\exp \left(-U_{i}\right) .
\end{aligned}
$$

Any farmer who is fully technically efficient will have a value of one, and farmers with values lying between zero and below one are said to be technically inefficient. The frontier production function is estimated by the maximum likelihood estimation technique which yields estimators for $\beta$ and $\gamma$, where

$$
\begin{gathered}
\gamma=\frac{\sigma u 2}{\sigma 2}, \\
\sigma 2=\sigma u 2+\sigma v 2 .
\end{gathered}
$$

The parameter $\gamma$ represents total variation of output from the frontier that is attributed to technical inefficiency, and it lies between zero and one, that is, $0<\gamma<1$.

Battese and Coelli [38] proposed a model in which the technical inefficiency effects in a stochastic production frontier are a function of other explanatory variables. The technical inefficiency effects, $U_{i}$, in equation (1) could be expressed as follows:

$$
U_{i}=\delta_{0}+\delta_{i} Z_{i j}+W_{i},
$$

where $Z_{i}$ represents the vector of farm specific variables, $\delta$ represents unknown coefficients of the farm specific inefficiency variables, and $W_{i}$ is the unobservable random variable assumed to be independently distributed with a positive half normal distribution.

2.4. Empirical Model. The Cobb-Douglas production function is employed for the investigation of technical efficiency and determinants of the inefficiency of smallholder ginger farms in Ilam, Nepal. It is argued that, as long as interest rests on efficiency measurements and not on an analysis of the general structure of the underlying production technology, the Cobb-Douglas specification provides an adequate representation of the production technology [39]. Moreover, its efficacy for multiple input modeling and handling multicollinearity, heteroscedasticity, and correlation justifies its wide application in economic literature [35]. For this study, the following Cobb-Douglas stochastic frontier production function was specified:

$$
\begin{aligned}
\ln Y_{i}= & \beta_{0}+\beta_{1} \ln X_{1 i}+\beta_{2} \ln X_{2 i}+\beta_{3} \ln X_{3 i} \\
& +\beta_{4} \ln X_{4 i}+\beta_{5} \ln X_{5 i}+V_{i}-\mathrm{U}_{\mathrm{i}},
\end{aligned}
$$

where

(i) $Y$ is the value of ginger output measured in kilograms

(ii) $X_{1}$ is the amount of seed in kilograms

(iii) $X_{2}$ is the amount of farmyard manure (FYM) in kilograms

(iv) $X_{3}$ is the amount of chemical fertilizers in kilograms

(v) $X_{4}$ is human labour in man-days

(vi) $X_{5}$ is bullock labour in hours

The estimation of an inefficiency model is performed simultaneously with that of the stochastic production frontier model. The inefficiency model based on Battese and Coelli [38] is specified as follows:

$$
\begin{aligned}
U_{i}= & \delta_{0}+\delta_{1} Z_{1 i}+\delta_{2} Z_{2 i}+\delta_{3} Z_{3 i}+\delta_{4} Z_{4 i}+\delta_{5} Z_{5 i} \\
& +\delta_{6} Z_{6 i}+\delta_{7} Z_{7 i}+\delta_{8} Z_{8 i}+\delta_{9} Z_{9 i}+\delta_{10} Z_{10 i}+W_{i}
\end{aligned}
$$

where

(i) $Z_{1}=$ gender of the farmer

(ii) $Z_{2}=$ age of the farmer

(iii) $Z_{3}=$ years of schooling

(iv) $Z_{4}=$ size of family

(v) $Z_{5}=$ annual income

(vi) $Z_{6}=$ member of farmer's group

(vii) $Z_{7}=$ member of cooperatives

(viii) $Z_{8}=$ training received on ginger cultivation 
(ix) $Z_{9}=$ subsidy received on seed

(x) $Z_{10}=$ area under ginger cultivation

The maximum likelihood estimate of the Cobb-Douglas stochastic frontier production was estimated using the STATA version 13.0 software. This software allows simultaneous estimation of production function coefficients and those of the technical inefficiency model.

\section{Results and Discussion}

3.1. Descriptive Statistical Analysis of the Variables. Table 1 presents the descriptive analysis of production and socioeconomic variables of smallholder ginger farmers of the study area. The table reveals that farmers use an average of $2,686.73 \mathrm{~kg}$ of seed per hectare and generate an output of about $8,169.40 \mathrm{~kg}$ of ginger which is far low than the district average of $14,690 \mathrm{~kg}$ [3]. This deviation in yield may be associated with the presence of inefficiency in ginger production. The average farmyard manure per hectare of ginger field is $22,288.54 \mathrm{~kg}$. Chemical fertilizer application is minimal with an average of $105.38 \mathrm{~kg}$ per hectare. This average is an estimate of all fertilizers used including nitrogen, phosphorus, and potassium. The recommended dose of nitrogen, phosphorous, and potassium per hectare is 80,50 , and $50 \mathrm{~kg}$, respectively, summing up to $180 \mathrm{~kg}$ per hectare [40]. This implies that farmers use less than the recommended dose of chemical fertilizers. Table 1 further reveals that the average human labour and bullock labour per hectare for ginger production is 496.02 man-days and 286.13 hours, respectively. This is justifiable because most of the activities involved are done manually.

On average, a typical ginger farmer in Ilam is 44.48 years old and spends seven years on education. The average household education ranges from 0 to 16 . This portrays a low level of education among ginger growers in the study area. Around $47 \%$ of the household have a joint type of family with members ranging from 5 to 10 . However, only 2-3 members from a household are involved in the ginger cultivation process. Both males and females are equally involved in ginger production.

Of the 1.01 hectare farm size owned by farmers, a mean of 0.10 hectare under ginger production indicates that farmers practice other alternatives like growing high-income generating products such as cardamom, vegetables, tea, and Thysanolaena (Nepalese broom grass). Table 1 also shows that only $46 \%$ of the sampled farmers have received training on ginger production which indicates that farmers lack skill and knowledge on good agricultural practices and efficient resource use. Kovacevic [41] reports that Nepalese farmers are routinely losing $90 \%$ of their ginger crops due to rhizome rot infestation and highlights the need for training on disease management to ginger farmers to enhance their productivity. $47 \%$ of the sampled farmers have received a subsidy from the Government of Nepal that is a $50 \%$ reduction in seed price. Around $81 \%$ have access to credit services and $88 \%$ of the interviewed farmers are members of local farmer's associations.
3.2. Result of the Stochastic Production Frontier. Table 2 shows the maximum likelihood estimates obtained from the Cobb-Douglas stochastic frontier for ginger production. The yield of ginger increases by $0.86 \%$ in response to a percentage increase in the amount of seed. The increase is significant at $1 \%$ level of significance. The implication of this is that value of ginger output is relatively elastic to seed and ginger yield can be increased by increasing the amount of seed. Our result is in line with the findings of several literature $[42,43]$. Similarly, a percentage increase in the amount of FYM increases the output of ginger by $0.95 \%$, which is statistically significant at $5 \%$ level of significance. The coefficients of human labour, bullock hour, and chemical fertilizer are negative. Human labour is statistically significant at $1 \%$ level. This implies that a percentage increase in human labour decreases the output of ginger by $0.64 \%$. The gamma estimate indicates the systematic variance that is unexplained by the production function and is the dominant source of random errors [44]. The gamma $(\gamma)$ value is 0.805 which indicates $80.5 \%$ of the total variation in ginger output is due to technical inefficiency.

3.3. Determinants of Inefficiency. In the inefficiency model, a negative coefficient means an increase in efficiency or a positive effect on productivity, whereas a positive coefficient means an increase in inefficiency or negative relation with productivity. Table 3 reveals that education and training were negative and statistically significant at $5 \%$ and $1 \%$ levels of significance. This implies that an increase in the level of education decreases inefficiency. A year increase in the schooling year of the household head increases the technical efficiency by $0.010 \%$. This result is consistent with the findings of several studies $[45,46]$. Education has a positive influence on technical efficiency since educated farmers have a great ability to adopt new technologies and innovations. Farmers with a low level of education provide poor supervision to farms and are slower to respond to emergencies such as an outbreak of crop disease [47].

Similarly, it is evident that farmers who have received training on ginger production have higher technical efficiency by $0.085 \%$ compared to those who have not received training. This may be due to the fact that training provides the farmers with new information in terms of input utilization, soil conservation with multipurpose vegetative crops, disease and pest management, marketing their final outputs, technology adoption, and saving aspects. Training and supplementary knowledge are better resource to help farmers improve their efficiency and sustainability [48]. Our result is consistent with the findings of Islam [49].

The coefficient of area under ginger production is positive and significant at $1 \%$ level of significance which implies that farmers cultivating ginger in a large area were technically inefficient than those cultivating ginger in a small area. This indicates that a $1 \%$ increase in the land area for ginger production increases the farm inefficiency by $0.049 \%$. The result is consistent with the findings of Njeru [47]. When the farmers have higher land holding, they rarely invest in improving land productivity [50]. 
TABLE 1: Statistics of ginger farmers in Ilam, Nepal.

\begin{tabular}{|c|c|c|c|c|c|}
\hline Variables & Unit/label & Mean & Standard deviation & Minimum & Maximum \\
\hline Seed & $\mathrm{kg} / \mathrm{ha}$ & 2686.73 & 1350.46 & 786.40 & 7864 \\
\hline Farmyard manure & $\mathrm{kg} / \mathrm{ha}$ & 22288.54 & 1968.17 & 175 & 10500 \\
\hline Chemical fertilizers & $\mathrm{kg} / \mathrm{ha}$ & 105.38 & 166.41 & 0 & 884.70 \\
\hline Human labour & Man-days/ha & 496.02 & 121.05 & 255.58 & 884.70 \\
\hline Bullock labour & Hours/ha & 286.13 & 113.96 & 50 & 470 \\
\hline Ginger output & $\mathrm{kg} / \mathrm{ha}$ & 8169.40 & 4375.82 & 2201.92 & 21000 \\
\hline Gender & $\begin{array}{l}\text { Male: } 1 \\
\text { Female: } 0\end{array}$ & 0.5 & 0.502 & 0 & 1 \\
\hline Age & Years & 44.48 & 12.31 & 26 & 75 \\
\hline Education & Years of schooling & 7 & 4.25 & 0 & 16 \\
\hline Family type & $\begin{array}{l}\text { Joint: } 1 \\
\text { Small: } 0\end{array}$ & 0.47 & 0.50 & 0 & 1 \\
\hline Annual income & NRs & 221500 & 163788 & 30000 & 900000 \\
\hline Member of farmer's group & $\begin{array}{l}\text { Yes: } 1 \\
\text { No: } 0\end{array}$ & 0.88 & 0.32 & 0 & 1 \\
\hline Member of cooperatives & $\begin{array}{l}\text { Yes: } 1 \\
\text { No: } 0\end{array}$ & 0.82 & 0.38 & 0 & 1 \\
\hline Training received & $\begin{array}{l}\text { Yes: } 1 \\
\text { No: } 0\end{array}$ & 0.46 & 0.50 & 0 & 1 \\
\hline Subsidy on seed & $\begin{array}{l}\text { Yes: } 1 \\
\text { No: } 0\end{array}$ & 0.47 & 0.50 & 0 & 1 \\
\hline Ginger farm size & Hectare & 0.10 & 0.08 & 0.02 & 0.40 \\
\hline Total land holding & Hectare & 1.01 & 0.84 & 0.05 & 3.81 \\
\hline
\end{tabular}

TABLE 2: Maximum likelihood estimates of stochastic frontier production function for ginger farming.

\begin{tabular}{|c|c|c|c|c|}
\hline Variables & Coefficient & Standard error & $z$ & $P$ value \\
\hline Constant term & $3.423^{* * *}$ & 0.212 & 16.08 & $\leq 0.001$ \\
\hline Seed & $0.864^{* * *}$ & 0.532 & 16.25 & $\leq 0.001$ \\
\hline Farmyard manure & $0.953^{* *}$ & 0.416 & 2.29 & 0.022 \\
\hline Chemical fertilizers & -0.006 & 0.164 & -0.41 & 0.685 \\
\hline Human labour & $-0.644^{* * *}$ & 0.846 & -7.61 & $\leq 0.001$ \\
\hline Bullock labour & -0.083 & 0.522 & -1.61 & 0.108 \\
\hline \multicolumn{5}{|l|}{ Variance parameters } \\
\hline $\operatorname{Sigma} v$ & 0.105 & 0.039 & & \\
\hline Sigma $u$ & 0.435 & 0.054 & & \\
\hline Sigma $^{2}$ & 0.200 & 0.042 & & \\
\hline Lambda & 4.142 & 0.086 & & \\
\hline Gamma & 0.805 & & & \\
\hline \multicolumn{5}{|l|}{ Observations $=100$} \\
\hline \multicolumn{5}{|l|}{ Wald $\mathrm{Chi}^{2}(5)=423.58$} \\
\hline \multicolumn{5}{|l|}{ Prob $>\mathrm{Chi}^{2}=0.000$} \\
\hline Log likelihood $=-9.293$ & & & & \\
\hline
\end{tabular}

${ }^{* * *},{ }^{* *}$, and ${ }^{*}$ indicate statistical significance at $1 \%, 5 \%$, and $10 \%$ probability level, respectively.

TABLE 3: Empirical estimates of factors that influence technical inefficiencies.

\begin{tabular}{|c|c|c|c|c|}
\hline Variable & Coefficient & Standard error & $z$ & $P$ value \\
\hline Constant term & 0.196 & 0.138 & 1.42 & 0.156 \\
\hline Gender & 0.012 & 0.031 & 0.41 & 0.683 \\
\hline Age & 0.000 & 0.001 & 0.29 & 0.771 \\
\hline Education & $-0.010^{* *}$ & 0.004 & -2.81 & 0.029 \\
\hline Family size & 0.008 & 0.029 & 0.29 & 0.771 \\
\hline Annual income & $7.22 e-08$ & $9.99 e-08$ & 0.72 & 0.470 \\
\hline Member of farmer's group & -0.004 & 0.041 & -0.10 & 0.920 \\
\hline Member of cooperatives & $-0.063^{*}$ & 0.034 & -1.83 & 0.067 \\
\hline Training received & $-0.085^{* * *}$ & 0.029 & -2.94 & 0.003 \\
\hline Subsidy on seed & -0.018 & 0.026 & -0.70 & 0.485 \\
\hline Area under ginger production & $0.049^{* * *}$ & 0.009 & 5.08 & $\leq 0.001$ \\
\hline
\end{tabular}

${ }^{* * *},{ }^{* *}$, and ${ }^{*}$ indicate statistical significance at $1 \%, 5 \%$, and $10 \%$ probability level, respectively. 


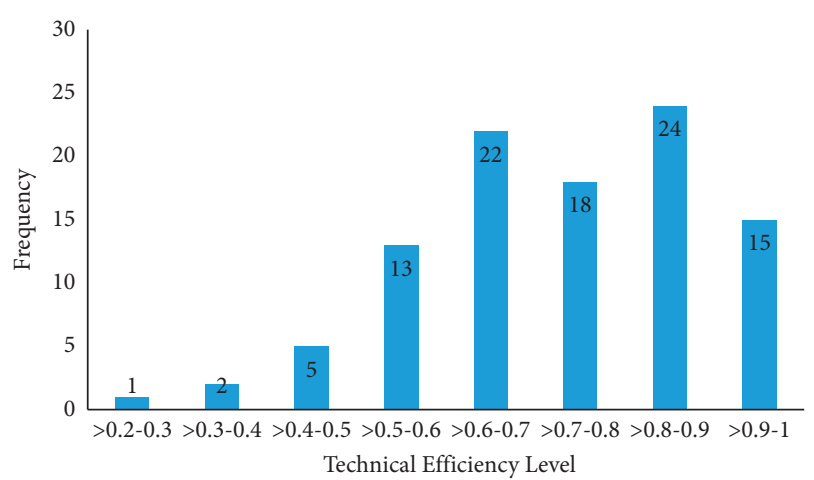

Figure 1: Farmers operating at different technical efficiency levels.

Similarly, the coefficient of membership of cooperatives is negative and significant at a $10 \%$ level of significance. This implies that farmers having membership in cooperatives are technically efficient than nonmembers. Agriculture cooperative plays an important role in improving efficiency by providing easy access to productive inputs and embedded support services such as training, information, and extension on input application [51].

The membership of farmer's group and subsidy on seed have a negative relation to technical inefficiency. Being a member of a farmer's group, farmers get the opportunity to interact with each other and learn about improved agricultural technologies which ultimately contributes to higher yield and make them technically efficient [52]. Subsidy on seed is aimed at making seed available to the farmers at below-market cost to increase productivity and profitability. Our result implies that subsidy reduces the technical inefficiency, although statistically not significant.

3.4. Technical Efficiency of Ginger Production. The majority of the ginger farmers (24\%) are operating at a technical efficiency level of $>0.8-0.9$ followed by $22 \%$ at $>0.6-0.7$ (Figure 1). The average technical efficiency of ginger production in the Ilam district of Nepal is $67.8 \%$ which indicates that there is still scope for increasing the production by $32.2 \%$ with the existing technologies and available resources. Farmers should focus on wise use of existing resources and technologies to generate higher ginger production.

\section{Conclusion and Policy Implications}

In this study, the technical efficiency of ginger production was investigated in a sample of 100 ginger-producing households in the Ilam district of Nepal using the stochastic frontier production model. The explanatory variables of technical inefficiencies were also estimated. The result shows that the average technical efficiency is $67.8 \%$, implying that ginger farmers in Ilam are not fully efficient, and there is a scope for improving the efficiency by addressing important variables that either positively or negatively influence the level of efficiency through policy formulation. The positive coefficients of seed and FYM reveal that the production of ginger is positively elastic with the change in inputs. Therefore, farmers must be encouraged to increase the amount of seed and FYM to improve their productivity. This can be done by providing them easy access to quality seeds through subsidy and providing them training on preparing FYM and compost manure using local materials. This will lead to higher productivity and ultimately higher technical efficiency.

Since human labour and bullock hours were negatively related to ginger yield, farm mechanization must be promoted as it reduces the human labour and bullock labour required to carry out agronomic operations. This can be done by the establishment of custom hiring centres in rural areas or by the provision of small farm machinery to farmer's groups. The empirical findings reveal that variables such as education level and training displayed negative relation to technical inefficiency. This implies that any increase in these variables decreases the technical inefficiencies. Thus, policy formulations should be undertaken to provide basic education to both old and young farmers. Similarly, the provision of training on the efficient utilization of existing resources must be done to improve technical efficiency. The study recommends deploying agriculture trainers or extension officers in rural areas to facilitate the dissemination of new technologies.

Membership in cooperatives was found negative and significant implying that farmers who are members of agricultural cooperatives are technically efficient than the farmers who are nonmembers. Thus, the study recommends the formulation of policies that encourage farmers to join cooperatives and farmer's associations. In addition to this, ginger-based cooperative package can be targeted to farmers to further improve the technical efficiency of ginger production. Area under ginger production was found positive and significant to inefficiency implying that farmers with a large area under ginger cultivation are technically less efficient than farmers having less area under ginger. Thus, training programs could be targeted to large ginger growers to improve their cultivation techniques and increase their technical efficiency. This study recommends the future researchers to focus on factors that influence technical inefficiencies such as membership in cooperatives, area under ginger cultivation, and subsidy on seed as these factors are important in terms of policy development. Future researchers could also replicate the study in other productive areas of the country with a larger sample size to get a better estimate of technical efficiency nationwide.

\section{Data Availability}

The data used to support the findings of this study are available from the corresponding author upon request.

\section{Conflicts of Interest}

The authors declare that there are no conflicts of interest regarding the publication of this paper.

\section{References}

[1] MoF, Economic Survey 2017/18, Ministry of Finance, Government of Nepal, Kathmandu, Nepal, 2018. 
[2] L. Zoder, "Ginger sector in Nepal," Trade Promotion Programme (TPP), Deutsche Gesellschaft für Internationale Zusammenarbeit (GIZ) GmbH, National Trust for Nature Conservation (NTNC) Complex, Lalitpur, Nepal, 2017.

[3] MoALD, Statistical Information on Nepalese Agriculture, Ministry of Agriculture and Livestock Development, Government of Nepal, Kathmandu, Nepal, 2021.

[4] MoALD, Statistical Information on Nepalese Agriculture, Ministry of Agriculture and Livestock Development, Government of Nepal, Kathmandu, Nepal, 2018.

[5] M. Basnet and H. Gurung, "Influence of mother rhizome retrieval and organic treatment of the retrieved plants on economic yield of ginger at Salyan, Nepal," Journal of the Institute of Agriculture and Animal Science, vol. 35, no. 1, pp. 203-209, 2018.

[6] S. Devkota, S. R. Ghimire, S. Y. Kim, and D. H. Sin, "Production status and export analysis of ginger in Nepal," The Journal of the Korean Society of International Agriculture, vol. 21, no. 2, pp. 75-80, 2010.

[7] B. Adhikari, Nepal Ginger Profile 2016: An Assessment of Commercial Ginger Cultivated in Nepal, Nepal Market Development Nepal \& Ginger Producers and Traders, Kathmandu, Nepal, 2016.

[8] USAID, Value Chain/Market Analysis of the Ginger SubSector in Nepal, USAID, Nepal, 2011.

[9] R. Adhikari, "The kathmandu post," 2018, https:// kathmandupost.com/money/2018/01/15/ginger-acreageshrinks-with-prices-in-free-fall.

[10] NARC, Annual Report 2013/14, Government of Nepal, Nepal Agricultural Research Council. Ginger Research Programme, Salyan, Nepal, 2014.

[11] R. Baral, B. P. Kafle, D. Pandey, D. Shrestha, and D. Min, "Adoption of Good Agricultural Practice to increase yield and profit of ginger farming in Nepal," Journal of Horticultural Research, vol. 29, no. 1, pp. 55-66, 2021.

[12] B. E. Bravo-Ureta and L. Reigler, "Dairy farm efficiency measurement using stochastic frontier and neoclassical duality," American Journal of Agricultural Economics, vol. 73, pp. 421-428, 1991.

[13] B. Carlsson, "The measurement of efficiency in production: an application to Swedish manufacturing industries 1968," The Swedish Journal of Economics, vol. 74, no. 4, pp. 468-485, 1972.

[14] S. O. Olayide and E. O Heady, Introduction to Agricultural Production Economics, University Press, Ibadan, Nigeria, 1982.

[15] N. G. Malinga, M. B. Masuku, and M. O. Raufu, "Comparative analysis of technical efficiencies of smallholder vegetable farmers with and without credit access in swazil and the case of the hhohho region," International Journal of Sustainable Agricultural Research, vol. 2, no. 4, pp. 133-145, 2015.

[16] T. J. Coelli, D. S. P. Rao, and G. Battese, An Introduction to Efficiency and Productivity Analysis, Kluwer Academic Press, Boston, MA, USA, 1998.

[17] A. Charnes, W. W. Cooper, and E. Rhodes, "Measuring the efficiency of decision making units," European Journal of Operational Research, vol. 2, no. 6, pp. 429-444, 1978.

[18] D. J. Aigner and S. F. Chu, "Estimating the industry production function," The American Economic Review, vol. 58, pp. 826-839, 1968.

[19] M. Ali and M. A. Chaudhry, "Inter-regional farm efficiency in Pakistan's Punjab: a frontier production function study," Journal of Agricultural Economics, vol. 41, no. 1, pp. 62-74, 1990.
[20] S. N. Afriat, "Efficiency estimation of production functions," International Economic Review, vol. 13, no. 3, pp. 568-598, 1972.

[21] E. Fleming, P. Fleming, H. Rodgers, G. Griffiten, and D. Johnston, Animal Efficiency in an Intensive Beef Production, Armidale: Genetic Breeding Unit, University of New England, Armidale, Australia, 2005.

[22] R. R. Schippers, African Indigenous Vegetables. An Overview of the Cultivated Species, Natural Resources Institute/ACP-EU Technical Centre for Agricultural and Rural Cooperation, Chathan, UK, 2000.

[23] D. Aigner, C. A. K. Lovell, and P. Schmidt, "Formulation and estimation of stochastic Frontier production function models," Journal of Econometrics, vol. 6, no. 1, pp. 21-37, 1977.

[24] J. E. Kirkley, D. Squires, and I. E. Strand, “Assessing technical efficiency in commercial fisheries: the Mid-Atlantic sea scallop fishery," American Journal of Agricultural Economics, vol. 20, pp. 31-34, 1995.

[25] GoN, District Profile, Ilam- 2074, National Planning Commision, Central Bureau of Statistics, Government of Nepal, Kathmandu, Nepal, 2017.

[26] E. Elahi, Z. Khalid, M. Z. Tauni, H. Zhang, and X. Lirong, "Extreme Weather Events Risk to Crop-Production and the Adaptation of Innovative Management Strategies to Mitigate the Risk: A Retrospective Survey of Rural Punjab, Pakistan," Technovation, pp. 0166-4972. In press, 2021.

[27] E. Elahi, H. Zhang, X. Lirong, Z. Khalid, and H. Xu, "Understanding cognitive and socio-psychological factors determining farmers' intentions to use improved grassland: implications of land use policy for sustainable pasture production," Land Use Policy, vol. 102, no. C, Article ID 105250, 2021.

[28] N. Dang, "Estimation of technical efficiency and its determinants of white maize production in Vinh long province: a stochastic production frontier approach," Review of Integrative Business and Economics Research, vol. 6, no. 4, pp. 341352, 2017.

[29] T. J. Coelli, A Guide to Frontier 4.1: A Computer Program for Stochastic Frontier Production and Cost Function Estimation, Armidale, Australia, 1994.

[30] C. I. Ezeh, "A comparative study of Fadama and non Fadama crop farmers in Osisioma-Ngwa L.G.A, Abia State, Nigeria," Journal of Sustainable Tropical Agriculture Research, vol. 11, pp. 26-31, 2004.

[31] G. Abebe, "Off-farm income and technical efficiency of smallholder farmers in Ethiopia: a stochastic frontier analysis," Master's thesis, Swedish University of Agricultural Sciences, Uppasala, Swedan, 2014.

[32] J. Haji and H. Andersson, "Determinants of efficiency of vegetable production in smallholder farms: the case of Ethiopia," Food Economics-ActaAgriculturaeScandinavica, vol. 3, no. 3-4, pp. 125-137, 2006.

[33] B. C. Okoye, A. Abass, B. Bachwenkizi et al., "Differentials in technical efficiency among smallholder cassava farmers in Central Madagascar: a Cobb Douglas stochastic Frontier production approach," Cogent Economics and Finance, vol. 4, no. 1, p. $568,2016$.

[34] G. T. Wudineh and G. Endrias, "Technical efficiency of smallholder wheat farmers: the case of Welmera district, Central Oromia, Ethiopia," Journal of Development and Agricultural Economics, vol. 8, no. 2, pp. 39-51, 2016.

[35] M. M. Kavoi, E. Najjuma, and R. Mbeche, "Assessment of technical efficiency of open field production in Kiambu country, Kenya (stochastic Frontier approach)," The Journal of Agriculture, Science and Technology, vol. 17, no. 2, 2016. 
[36] W. Meeusen and J. van den Broeck, "Efficiency estimation from cobb-douglas production functions with composed error," International Economic Review, vol. 18, no. 2, pp. 435-444, 1977.

[37] G. Battesse, "Frontier production function and technical efficiency: a survey of empirical applications in agricultural economics," Agricultural Economics Review, vol. 7, pp. 185208, 1992.

[38] G. E. Battese and T. J. Coelli, "A model for technical inefficiency effects in a stochastic Frontier production function for panel data," Empirical Economics, vol. 20, no. 2, pp. 325-332, 1995.

[39] J. Binam, J. Tonye, and N. Wandji, "Source of technical efficiency among smallholder maize and peanut farmers in the slash and burn agriculture zone of Cameroon," Journal of Economic Cooperation, vol. 26, pp. 193-210, 2005.

[40] MoALD, Agriculture Diary, Lalitpur: Ministry of Agriculture and Livestock Development, Agriculture Information and Training Centre, Lalitpur, Nepal, 2021.

[41] M. Kovacevic, "Trade for development news by EIF," 2019, https://trade4devnews.enhancedif.org/en/impact-story/ nepal-sees-ginger-revival.

[42] S. T. Folorunson and K. M. Adenuga, "An analysis of technical efficiency of ginger crop production in Jaba local government area, Kaduna State, Nigeria," Advances in Applied Science Research, vol. 4, no. 5, pp. 85-90, 2013.

[43] J. Nandi, "Technical efficiency of ginger production in kaduna state, Nigeria: the stochastic frontier approach," Journal of Vocational and Technical Education, vol. 6, no. 1, 2011.

[44] G. Umoh, "Resource use efficiency in urban farming: an application of stochastic frontier production function," International Journal of Agriculture and Biology, vol. 8, no. 1, pp. 37-44, 2006.

[45] A. K. Mishra, S. Shaik, A. R. Khanal, and S. Bairagi, "Contract farming and technical efficiency: evidence from low-value and high-value crops in Nepal," Agribusiness, vol. 34, no. 2, pp. 426-440, 2017.

[46] N. Khanal and K. L. Maharjan, "Technical efficiency of rice seed growers in the Tarai region of Nepal," Journal of Rural Problems, vol. 49, no. 1, pp. 27-31, 2013.

[47] J. Njeru, Factors Influencing Technical Efficiencies Among Selected Wheat Farmers in Uasin Gishu District, Kenya, AERC Research Paper 206, Moi University, Nairobi, Kenya, 2010.

[48] H. D. Nguyen, T. Ngo, T. D. Le, H. Ho, and H. T. H. Nguyen, "The role of knowledge in suatainable agriculture: evidences from rice farm's technical efficiency in hanoi, Vietnam," Sustainability, vol. 11, 2019.

[49] M. S. Islam, K. M. Rahman, and M. K. Hasan, "Profitability and resource use efficiency of producing major spices in Bangladesh," The Bangladesh Journal of Agricultural Economics, vol. 34, no. 1-2, pp. 1-13, 2011.

[50] A. Belete, "Analysis of technical efficiency in maize production in Guji Zone: stochatic Frontier model," Agriculture \& Food Security, vol. 9, no. 15, 2020.

[51] G. T. Abate, G. N. Francesconi, and K. Getnet, "Impact of agricultural cooperatives on smallholders' technical efficiency: empirical evidence from Ethiopia," Annals of Public and Cooperative Economics, vol. 85, no. 2, pp. 257-286, 2014.

[52] S. Subedi, Y. N. Ghimire, M. Kharel, S. P. Adhikari, J. Shrestha, and B. K. Sapkota, "Technical efficiency of rice production in Terai district of Nepal," Journal of Agriculture and Natural Resources, vol. 3, no. 2, pp. 32-44, 2020. 